\title{
Creation and validation of a checklist for blood transfusion in children
}

\author{
Construção e validação de checklist para transfusão sanguínea em crianças \\ Construcción y validación de lista de comprobación (checklist) para la transfusión de sangre en niños
}

$\begin{gathered}\text { Carolina Martins Bezerra', Maria Vera Lúcia Moreira Leitão Cardoso', } \\ \text { Grazielle Roberta Freitas da Silva", Elisa da Conceição Rodrigues"' }\end{gathered}$
'Universidade Federal do Ceará. Fortaleza, Ceará, Brazil.
"Universidade Federal do Piauí. Teresina, Piauí, Brazil.
How to cite this article:
'" Universidade Federal do Rio de Janeiro, Nursing School Anna Nery. Rio de Janeiro, Rio de Janeiro, Brazil.
Bezerra CM, Cardoso MVLML, Silva GRF, Rodrigues EC. Creation and validation of a checklist for blood transfusion in
children. Rev Bras Enferm [Internet]. 2018;71(6):3020-6. DOI: http://dx.doi.org/10.1590/0034-7167-2018-0098

Submission: 03-07-2018 Approval: 05-01-2018

\begin{abstract}
Objective: To describe the process for creating and validating a checklist for blood transfusion in children. Method: Methodological study, conducted from November 2016 to May 2017, developed in two stages. The content of the items that compose the instrument was based on scientific evidence and submitted to specialized nurses for content validation. We applied the Content Validity index, considering the value $\geq 0.80$. Results: The content was considered valid with global CVI of 0.87. Suggestions for adjustments, such as deletion, replacement, and addition of terms, were included in the final version, which consisted of 14 items and 56 subitems. Conclusion: The checklist for blood transfusion in children was considered a technology with valid content to be used in the transfusion performed by nurses, thus contributing to transfusion safety in children.
\end{abstract}

Descriptors: Blood Transfusion; Children; Checklist; Pediatric Nursing; Patient Safety.

RESUMO

Objetivo: Descrever o processo de construção e validação de conteúdo de um checklist para transfusão sanguínea em crianças. Método: Estudo metodológico, realizado de novembro de 2016 a maio de 2017, desenvolvido em duas etapas. O conteúdo dos itens que compõem o instrumento foi fundamentado em evidências científicas e submetido à apreciação de enfermeiros especialistas para validação de conteúdo. Aplicou-se o Índice de Validade de Conteúdo, aceitando-se o valor $\geq 0,80$. Resultados: O conteúdo foi considerado válido com IVC global de 0,87. As sugestões de ajustes como exclusão, substituição e acréscimo de termos foram inseridas na versão final, que se constituiu de 14 itens e 56 subitens. Conclusão: O checklist para transfusão sanguínea em crianças foi considerado tecnologia com conteúdo válido para ser utilizado no ato transfusional desempenhado por enfermeiros, contribuindo, assim, para segurança transfusional em crianças.

Descritores: Transfusão Sanguínea; Criança; Checklist; Enfermagem Pediátrica; Segurança do Paciente.

\section{RESUMEN}

Objetivo: Describir el proceso de construcción y validación de contenido de una lista de comprobación (checklist) para la transfusión de sangre en niños. Método: Estudio metodológico, fue realizado de noviembre de 2016 a mayo de 2017, fue desarrollado en dos etapas. El contenido de los elementos que componen el instrumento ha sido fundamentado en las evidencias científicas y ha sido sometido a la apreciación de enfermeros expertos para la validación de contenido. Se ha sido aplicado el Índice de Validez de Contenido, y el valor $\geq 0,80$ era aceptado. Resultados: El contenido ha sido considerado válido con IVC global de 0,87. Las sugerencias de arreglos como la exclusión, la sustitución y el incremento de términos han ido insertadas en la versión final, que se ha constituido de 14 elementos y 56 subelementos. Conclusión: La lista de comprobación (checklist) para la transfusión de sangre en niños ha sido considerado tecnología con contenido válido para ser utilizado en el acto transfusional que ha sido desempeñado por enfermeros, contribuyendo, así, para la seguridad transfusional en niños.

Descriptores: Transfusión de Sangre; Niño; Lista de Comprobación (Checklist); Enfermería Pediátrica; Seguridad del Paciente. 


\section{INTRODUCTION}

Blood transfusion is commonly performed in hospitals, especially in surgical and intensive care units, frequently occurring among pediatric patients. It can be regarded as whole-blood transfusion or transfusion of blood components from one individual to another, representing an essential support measure to health care ${ }^{(1)}$.

Transfusion of red blood cells in pediatrics showed that $8 \%$ of transfusions occur with newborns, $14 \%$ with children aging between one month and one year, and $78 \%$ in those aging over one year, with a median of five years of age. As for the diagnosis, $53 \%$ were onco-hematologic patients; $26 \%$, surgical patients; and $13 \%$, patients who underwent a heart surgery ${ }^{(2)}$.

Blood transfusion is a multiprofessional process with several interconnected stages, predisposing the frequent occurrence of errors. On the other hand, human failures interfere directly in patient safety, defined by the World Health Organization (WHO) as the reduction to a minimum acceptable risk of unnecessary damage, associated with health care ${ }^{(3)}$. However, most transfusion errors occur in the patients' identification at the time of collecting the blood sample, or due to the inadequate verification on the bed prior the transfusion of blood components ${ }^{(4)}$.

In this sense, data from a research mention interruptions due to phone calls and requests for products; ignorance or lack of understanding by professionals of other areas, such as nursing; pressure for the quick delivery of components; insufficient staff to handle the workload; individuals who do not follow standard operating procedures; and slips or individual lapses as the reasons why errors occur in the hospital transfusion service ${ }^{(5)}$.

In most healthcare institutions, nurses are responsible for performing blood transfusion. An integrative review pointed out that these healthcare professionals rarely manage to complete an activity without being interrupted, especially in the pediatric unit, being that with the greater number of interruptions, which often occur when providing direct care to the patients ${ }^{(6)}$. Added to these indicators, the nursing workload and stress/burnout syndrome were related as factors that negatively affect patients' safety. Among incidents related to these factors, are included those due to the administration of blood components ${ }^{(7)}$.

Resolution no. 0511/2016 of the Brazilian Federal Council of Nursing (from Portuguese, Conselho Federal de Enfermagem - Cofen ${ }^{(8)}$ approves the technical standard that provides for the performance of nurses in hemotherapy, in order to ensure a competent, resolutive, and safe nursing care. Especially, improvements in nursing care are essential to safely perform transfusion. It can be accomplished by practicing simple activities such as using operational procedures adapted to the daily routine ${ }^{(9)}$ and including the use of technology to avoid manageable risks ${ }^{(10)}$.

Therefore, nursing practice has been constantly influenced by technological advances, such as the use of instruments - for instance, the checklist -, that combine scientific knowledge and practical assistance. However, it is necessary for them to be validated as effective technologies for health care, thus providing a more qualified and efficient care, avoiding mistakes arising from lapses in memory or slips. For instance, there are the worldwide well-disseminated use of the Surgical Safety Checklist and the Safe Childbirth Checklist, both of the $\mathrm{WHO}^{(11-12)}$, which have been contributing to patients' safety.
In pediatrics, the quality of nursing care focusing on the safety of hospitalized children encompasses, among other aspects, the quality of the information gathered in medical records and the use of checklists in the procedures ${ }^{(13)}$.

The use of checklist indicates the need for consulting written materials to support decision-making in hospitals in order to ensure nurses - who are legally responsible for the transfusion process - the reduction of the errors of omission and the variation in the care provided to children who underwent blood transfusion. Recognizing the magnitude of the transfusion process and considering that there are gaps between theoretical knowledge and clinical practice, and the creation and use of technologies such as the checklist, we questioned: which nursing care practices should compose a checklist for blood transfusion in children? Has the checklist for blood transfusion valid content to be used in clinical practice with children?

\section{OBJECTIVE}

To describe the process of creating and validating a checklist for blood transfusion in children.

\section{METHOD}

\section{Ethical aspects}

The study was approved by the Research Ethics Committee of Universidade Federal do Ceará - Plataforma Brasil. Specialized nurses who have agreed to participate in this research have signed an Informed Consent Form.

\section{Study design, location, and period}

This a methodological study, developed in two stages: bibliographic survey for creating the checklist for children undergoing blood transfusion and, later, content validation of the instrument by specialized nurses.

The first stage of the study took place from November 2016 to January 2017, with the search and selection of scientific evidences in the following databases: Scientific and Technical Literature of Latin America and the Caribbean (Lilacs), Cochrane, Cumulative Index to Nursing and Allied Health Literature $(\mathrm{Cl}-$ NAHL), Medical Publications Portal (PubMed), and Scopus. We used the health terminology consulted in Health Sciences Descriptors (DeCS) and Medical Subject Headings (MeSH), with the controlled descriptors "blood transfusion," "nursing care," and "child". In order to expand the range of publications, we used the Boolean "AND" for the intersection of descriptors.

The validity of an instrument measures exactly what you intend to measure, and for such we used techniques including the validity of content ${ }^{(14)}$. The completion of this stage consisted in the analysis of experts in hemotherapy and/or children's health as well as semantic analysis of items that composed the checklist for blood transfusion in children.

\section{Sample: criteria for selection of specialized nurses}

Considering the diversity of references for determining the profile of the expert in research and no standardization for such, we opted for electing their own criteria based on literature ${ }^{(15-16)}$, 
which were: master's degree in nursing (2 points ); PhD degree in nursing (3 points); thesis/dissertation on hemotherapy and/or health of hospitalized children (2 points); technical proficiency, residency and/or specialization in hemotherapy and/or health of hospitalized children (2 points); healthcare practice of at least five years in hemotherapy and/or pediatrics in hospital environment (2 points); and, finally, participation in research groups addressing the topic (1 point). Were considered specialized nurses those who have reached the minimum score of five points.

Researchers selected the experts considering the prior knowledge of the professional as well as by using the Snowball Sampling Technique ${ }^{(14)}$. Confirmation of the criteria for classifying the experts was made through the evaluation of the Curriculum Lattes.

The contact was made by electronic means, initially, by sending an invitation letter and, after acceptance of the nurse, by sending the informed consent form, the assessment instrument, and the created checklist. The final sample was composed of 14 nurses who have agreed to participate in the study as experts. It is noteworthy that despite the even number, there was no stalemate in the evaluation.

\section{Study protocol}

After accepting to participate in the research, we sent the instrument for content validation to the 14 experts by e-mail. Such was divided into two parts: $1 \mathrm{st}$ ) identification data of specialized nurses and 2nd) instructions for fulfilling the instrument and evaluation items of the checklist. We established a 20-day deadline for returning the fully-completed instrument. If there was no return of the instrument, we extended the deadline by sending an e-mail reminding the participation in the study, which ended in a maximum time of 45 days.

The experts gave their opinions about clarity, pertinence, and relevance of the construct items, and to do so, they used the dichotomous answers "YES" or "NO." As for relevance, we used the Likert scale, with four support levels: 1 = Irrelevant; 2 = Hardly relevant; 3 = Relevant; and $4=$ Highly relevant. For those items responded with 1 and 2 scores, we requested justifications, which were revised, and researchers decided on the maintenance of such in the contents of the checklist for blood transfusion in children.

\section{Analysis of results and statistics}

For content validation, we used the Content Validity Index $(\mathrm{CVI})$ to verify consistency between experts. Such was calculated by dividing the number of concordant items of the experts, i.e., items scored by experts with 3 and 4 scores, by the total number of items in the checklist ${ }^{(17)}$. As acceptable, we considered the index equal to or greater than $80 \%(\mathrm{CVI} \geq 0.8$ ), both for the evaluation of each item and the overall evaluation of the instrument ${ }^{(18)}$.

Data were stored in a Microsoft Excel 2010 spreadsheet. After being coded and tabulated, data were analyzed through descriptive statistics. Considering the literature pertinent to the object of study, the instrument was redesigned in accordance with the suggestions of the experts. As requested by the researchers, changes were made in the final version of the construct.

\section{RESULTS}

\section{First stage: bibliographic survey and creation of the checklist} for blood transfusion in children

The search and selection of scientific evidence resulted in 44 thousand publications by the association of descriptors. However, only nine articles contributed to the creation of the instrument. From the integrative review data, we identified items that composed the checklist, divided into: pretransfusion, transfusion, and post-transfusion nursing care. In the pre-transfusion stage, were listed: informed consent form, verification of blood components, children's identification, material selection, handwashing, and pre-medication. In the transfusion stage: verification of vital signs prior transfusion, venous access, transfusion of blood components, patients' follow-up, infusion time of blood components, and suspicion of transfusion reaction. And, finally, in the post-transfusion stage the surveyed nursing care were: verification of vital signs immediately after transfusion, disposal of the used material, verification of vital signs 1 hour after completing the transfusion, and children's records and follow-up for 24 hours after completing the transfusion.

In possession of the contents listed by the bibliographic survey, we started the creation process. The created checklist was of the "read-do" type, in which there is a list of tasks to be performed, usually by one person ${ }^{(19)}$. The instrument was based on the layout and the principles of simplicity, broad applicability, and measurability of the Surgical Safety Checklist of the World Health Organization ${ }^{(11)}$.

The checklist created for blood transfusion in children, similar to the Surgical Safety Checklist - WHO, divides the procedure into three stages (pre-transfusion, transfusion, and post-transfusion) concerning the nursing care aiming at transfusion safety, based on scientific evidence and on the expertise of researchers.

The preliminary version of the checklist was composed of 17 items and 61 subitems and, after validation, considering the experts' suggestions, it was modified regarding the content, resulting in the final version with 14 items and 56 subitems.

\section{Second stage: content validation and characterization of specialized nurses}

Participants were female, aging from 26 to 53 years, and average time of nursing training of 12.8 years. The academic profile indicated that the majority $(64.29 \%)$ hold a masters' degree in nursing. Regarding the occupation at the time of the survey, there was a predominance of teaching activities.

To be considered an expert, the evaluator needed to score between 5 and 14 points. Hence, after individual analysis of the evaluative instruments, we found that the maximum score assigned to the experts was 12 points, with a minimum score of 6 and a mean of 9 points. Such findings demonstrated satisfactory level of expertise of the selected nurses, since none obtained the minimum score (5 points).

In Table 1 we present the variables of experts' characterization, according to sociodemographic and academic data. 
Table 1 - Characterization of the experts participating in the study, Fortaleza, Ceará, Brazil, 2017

\begin{tabular}{|c|c|c|c|}
\hline Variables & n (14) & $\%$ & Mean \pm SD \\
\hline Age (years) & & & $36.7 \pm 0.7$ \\
\hline 26-35 & 9 & 64.3 & \\
\hline $36-45$ & 2 & 14.3 & \\
\hline $46-53$ & 3 & 21.4 & \\
\hline Training time (years) & & & $12.8 \pm 14.87$ \\
\hline $3-10$ & 8 & 57.1 & \\
\hline $11-18$ & 2 & 14.3 & \\
\hline $19-29$ & 4 & 28.6 & \\
\hline \multicolumn{4}{|l|}{ Participation in a research group } \\
\hline Yes & 13 & 92.9 & \\
\hline No & 1 & 7.1 & \\
\hline Time of participation in a research group (years) & & & $5.6 \pm 11.3$ \\
\hline $0-5$ & 6 & 42.9 & \\
\hline $6-11$ & 7 & 50.0 & \\
\hline $12-14$ & 1 & 7.1 & \\
\hline \multicolumn{4}{|l|}{ Current occupation } \\
\hline Healthcare professional & 2 & 14.3 & \\
\hline Teaching activities & 4 & 28.6 & \\
\hline Research activities & 1 & 7.1 & \\
\hline Healthcare and teaching activities & 1 & 7.1 & \\
\hline Healthcare, teaching, and research activities & 2 & 14.3 & \\
\hline Healthcare and research activities & 2 & 14.3 & \\
\hline Healthcare and other activities & 1 & 7.1 & \\
\hline Healthcare, teaching activities, and other activities & 1 & 7.1 & \\
\hline \multicolumn{4}{|l|}{ Certification } \\
\hline Specialization degree & 1 & 7.1 & \\
\hline Master's degree & 9 & 64.3 & \\
\hline PhD degree & 2 & 14.3 & \\
\hline Postdoctoral degree & 1 & 7.1 & \\
\hline Specialization and master's degree & 1 & 7.1 & \\
\hline Experts' scores & & & $9 \pm 10.3$ \\
\hline $6-9$ & 9 & 64.3 & \\
\hline $10-12$ & 5 & 35.7 & \\
\hline
\end{tabular}

Table 2 - Specialized nurses' content validation of items for the checklist for blood transfusion in children, Fortaleza, Ceará, Brazil, 2017

\begin{tabular}{clc}
\hline $\mathbf{N}$ & \multicolumn{1}{c}{ Content Validity items } & IVC \\
\hline 1 & Informed consent form & 0.65 \\
2 & Verification of blood components & 1.0 \\
3 & Children's identification & 1.0 \\
4 & Material selection & 0.59 \\
5 & Pre-medication & 1.0 \\
6 & Handwashing & 1.0 \\
7 & Verification of vital signs (prior transfusion) & 1.0 \\
8 & Venous access & 1.0 \\
9 & Transfusion of blood components & 1.0 \\
10 & Patients' follow-up & 1.0 \\
11 & Infusion time of blood components & 0.76 \\
12 & Suspicion of transfusion reaction & 0.76 \\
13 & Verification of vital signs (after completing the transfusion) & 1.0 \\
14 & Disposal of the used material & 0.65 \\
15 & Verification of vital signs 1 hour after completing the transfusion & 0.65 \\
16 & Records & 1.0 \\
17 & Children's follow-up for 24 hours after completing the transfusion & 0.76 \\
\hline Note: CVI - Content Validity Index.
\end{tabular}

Procedure for validating the checklist for blood transfusion in children

The application of CVI for each item individually obtained values that varied from minimum of 0.59 to maximum of 1 , which did not confer validity to all items of the instrument, as shown in Table 2. The global CVI, which was calculated by the mean of all items, accounted for 0.87 , validating the instrument as a whole.

When evaluating items of the checklist, concerning clarity, pertinence, and relevance of the nursing care provided to children undergoing transfusion, we perceived a high level of agreement between experts. However, some did not show minimum agreements in some interventions of the instrument, i.e., the agreement level was lesser than 0.8. As suggestions to correct these items, it was proposed, mostly, changes in the writing of interventions, being required rewording and deletion of some items for improving the checklist content.

Items that did not account for CVI $\geq 0.80$ and those that featured any suggestions or comments were analyzed again. Suggestions comprising acceptable scientific evidence were included in the instrument. In Chart 1 , we presented suggestions for items in the checklist that failed to obtain agreement on the assessment of the specialized nurses participating in the study.

\section{DISCUSSION}

The global CVI we found, 0.87, represents a satisfactory level of agreement between experts, since to verify the validity of new instruments there must be a minimum agreement of at least $80 \%$ or 0.8 between evaluators ${ }^{(18)}$. This cutoff point was also used by other authors for content validation of a data collection instrument at a neonatal unit ${ }^{(20)}$; and for a methodological study carried out in three stages for creating and validating a Standard Operating Procedure for identifying newborns with use of bracelets $^{(21)}$. According to Table 2, only in the items 1, 4, 11, 12, 14, 15, and 17 we had an agreement percentage lesser than the stipulated value $(<0.8)$. 
Chart 1 - Experts' suggestions concerning items that did not achieve agreement on the content validation for the checklist for blood transfusion in children, Fortaleza, Ceará, Brazil, 2017

\begin{tabular}{|l|l|}
\hline \multicolumn{1}{|c|}{ Items } & \multicolumn{1}{c|}{ Experts' suggestions } \\
\hline Consentimento informado & * Delete the item. \\
\hline Material selection & $\begin{array}{l}\text { * Describe in detail the materials used for the transfusion. } \\
\text { * Reword the item as for: preparation of the material. }\end{array}$ \\
\hline Infusion time of blood components & $\begin{array}{l}\text { * Standardize the maximum infusion time of } 4 \text { hours for all } \\
\text { blood components. }\end{array}$ \\
\hline Suspicion of transfusion reaction & * Replace "Required actions taken" with "Nursing interventions." \\
\hline Disposal of the used material & $\begin{array}{l}\text { * Add the title of the item "in proper site." } \\
\text { * Describe in detail how disposal must occur. }\end{array}$ \\
\hline Verification of vital signs 1 hour after completing the transfusion & * Delete the item. \\
\hline Children's follow-up for 24 hours after completing the transfusion & * Delete the item. \\
\hline
\end{tabular}

In the pre-transfusion stage, the informed consent form consists in the act of deciding, agreeing, and approving, on the part of patients or legal representatives, under medical responsibility, after being aware of information and explanations required for the procedures indicated for them ${ }^{(22)}$. Nurses are responsible for clarifying the procedure as well as the guidelines about the stages involving the transfusion and its possible complications ${ }^{(1)}$. Experts mentioned the deletion of the item since it is a medical activity, but such suffered a change in the title: "Nursing guidelines prior the procedure."

Concerning "material selection" (item 4), we noted that in the created checklist there is no description of the materials used by nurses in the transfusion, and such should be described, as suggested by some experts, for standardizing the clinical practice as well as the guidelines to recently-graduated nurses. By including this information, this item would become clearer. However, the choice and the required materials comprise a common stage for performing nursing procedures, not being an exclusive nursing care for transfusion. In addition, due to featuring the lower CVI (0.59) of the entire checklist, we excluded the item in the second version of the instrument.

As for the item "Infusion time for blood components," experts suggested to standardize the maximum infusion time to 4 hours for all blood components. The infusion time of blood components is, at most, of 4 hours; when this period is covered, transfusion should be interrupted and blood bags should be discarded ${ }^{(23)}$.

As for transfusion reactions, we observed that they affect lesser than $1 \%$ of patients ${ }^{(24)}$. The most common clinical manifestations include fever, chills, nausea, vomiting, diarrhea, flushing, itching, urticaria, respiratory whistle, dyspnea, headache, hypertension, chest pain and back pain, circulatory collapse, respiratory insufficiency, and shock ${ }^{(25)}$. When suspecting a transfusion reaction, it is recommended to interrupt the transfusion and immediately communicate the doctor. In cases of severe reactions, with life threatening, the resuscitation staff must be notified, registering the event in the medical records and taking the necessary actions, in accordance with the hemovigilance policy of the hospital unit ${ }^{(26)}$. Therefore, the experts recommended the replacement of the terms "Required actions taken" with "Nursing interventions."
The item addressing the disposal of the used material was excluded from the checklist due to the same exclusion criteria of item 4 .

Because of the divergence in literature regarding the minimum patients' follow-up, the permanence of item 15 (Verification of vital signs 1 hour after completing the transfusion) in the checklist was based on the results of the integrative review for creating such checklist, which pointed out the minimum followup of vital signs immediately prior the transfusion, 15 minutes after beginning the procedure, immediately after completing the procedure, and 1 hour after completing the transfusion ${ }^{(27)}$.

In the post-transfusion stage, experts opted for the exclusion of the item "children's follow-up for 24 hours after completing the transfusion." However, the nursing care provided to hospitalized patients with indications for blood transfusion begin at the time transfusion is requested and continue up to 24 hours after completing the transfusion.

The maximum time for the emergence of signs and symptoms of immediate transfusion reactions in the Brazilian Hemovigilance System is 24 hours $^{(28)}$, in such way children must be monitored until the deadline determined by the Brazilian legislation in order to avoid the emergence of these reactions. Since there was divergence between the opinion of experts and researchers regarding this item, we opted for keeping it on the instrument.

\section{Study limitations}

We highlight as one of the limitations of our study the difficulty in obtaining the return of the evaluative instruments responded in the proper time by the experts, resulting in the validation on the part of 14 specialized nurses only as well as the lack of external validation. We suggest further studies to be conducted.

\section{Contributions to the fields of nursing and health}

We believe that the study has contributed to transfusion safety in children. Hence, we expect the results may provide support for the daily practice of nurses, because the checklist serves as a script to guide the steps that professionals should take to ensure minimum safety to children undergoing transfusion, thus decreasing errors of omission and the variation in the nursing care provided to this population. 


\section{CONCLUSION}

The checklist for blood transfusion in children proved to be valid as for the content. Experts assessed the items that composed the instrument regarding clarity, pertinence, and relevance, in addition to making suggestions while creating the instrument. Their recommendations were followed, seeking to enhance the clarity of the items, in order to facilitate the reading, the understanding, and the applicability of the instrument. Further research on other types of validation shall be needed to test the validity and trustworthiness of the checklist.

\section{REFERENCES}

1. Fidlarczyk D, Ferreira SS. Enfermagem em Hemoterapia. Rio de Janeiro: MedBook; 2008.

2. New HV, Grant-Casey J, Lowe D, Kelleher A, Hennem S, Stanworth SJ. Red blood cell transfusion practice in children: current status and areas for improvement? a study of use of red blood cell transfusions in children and infants. Transfusion[Internet]. 2014[cited 2017 Apr 7];54(1):119-27. Available from: https://www.ncbi.nlm.nih.gov/pubmed/23808415

3. Bates DW. World Health Organization-WHO. Patient Safety. Research Introductory Course - Session 1. What is patient safety?[Internet]. 2012[cited 2018 Feb 10]. Available from: https://bit.ly/2BtqxSq

4. Bolton-Maggs PHb. Blood transfusion safety: patients at risk from human errors. Br J Hosp Med[Internet]. 2013 [cited 2017 Apr 7];74(10):544-5. Available from: https://www.ncbi.nlm.nih.gov/pubmed/24105304

5. Sorra J, Nieva V, Fastman BR, Kaplan H, Schreiber G, King M. Staff attitudes about event reporting and patient safety culture in hospital transfusion services. Tranfusion[Internet]. 2008[cited 2017 Feb 10];48:1934-42. Available from: https://www.ncbi.nlm. nih.gov/pubmed/18507747

6. Monteiro C, Avelar AFM, Pedreira MLG. Interruptions of nurses' activities and patient safety: an integrative literature review. Rev Latino-Am Enfermagem[Internet]. 2015[cited 2017 Dec 23];23(1):169-79. Available from: https://bit.ly/2s9eORN

7. Padilha GK, Barbosa RL, Andolhe R, Oliveira EM, Ducci AJ, Bregalda RS, et al. Nursing workload, stress/burnout, satisfaction and incidents in a trauma intensive care units. Texto Contexto Enferm[Internet]. 2017[cited 2017 Dec 23];26(3):1-8. Available from: http://www.scielo.br/pdf/tce/v26n3/en_0104-0707-tce-26-03-e1720016.pdf

8. Brasil. Conselho Federal de Enfermagem-Cofen. Resolução no 511, de 31 de março de 2016. Diário Oficial da União[Internet]. 2016[cited 2016 Dec 23]. Available from: http://www.cofen.gov.br/resolucao-cofen-no-05112016_39095.html

9. Lardemelle C, Auroy Y. [The nurse, a key player in transfusion safety]. Rev Infirm[Internet]. 2012[cited 2017 Feb 10];177:25-7. Available from: https://www.ncbi.nlm.nih.gov/pubmed/22372107 French.

10. Aulbach RK, Brient K, Clark M, Custard K, Davis C, Gecomo J, et al. Blood transfusions in critical care: improving safety through technology \& process analysis. Crit Care Nurs Clin North Am[Internet]. 2010[cited 2017 Apr 9];22(2):179-90. Available from: https://www.ncbi.nlm.nih.gov/pubmed/20541066

11. Brasil. Ministério da Saúde. Agência Nacional de Vigilância Sanitária. Organização Pan-Americana da Saúde. Segundo desafio global para a segurança do paciente: cirurgias seguras salvam vidas[Internet]. 2009[cited 2017 Mar 9]. Available from: http://bvsms. saude.gov.br/bvs/publicacoes/seguranca_paciente_cirurgias_seguras_guia.pdf

12. World Health Organization-WHO. Safe childbirth checklist implementation guide: improving the quality of facility-based delivery for mothers and newborns[Internet]. 2015[cited 2017 Jan 20]. Available from: http://www.ibes.med.br/novo/wp-content/themes/ bizwaytheme/upload/1449704747.pdf

13. Wegner W, Silva MUM, Peres MA, Bandeira LE, Frantz E, Botene DZA, et al. Patient safety in the care of hospitalised children: evidence for paediatric nursing. Rev Gaúcha Enferm[Internet]. 2017[cited 2017 Feb 10];38(1). Available from: http://www.scielo. br/pdf/rgenf/v38n1/en_0102-6933-rgenf-1983-144720170168020.pdf

14. Pasquali L. [Psychometrics]. Rev Esc Enferm USP[Internet]. 2009[cited 2018 Apr 9];43(Esp):992-9. Available from: http://www. scielo.br/pdf/reeusp/v43nspe/a02v43ns.pdf Portuguese.

15. Fering RJ. The Ferhing model. In Carrol-Johnson R, Paquete M, (Eds.). Classification of nursing diagnosis: proceedings of the tenth conference of North American Nursing Diagnoses Associations. Philadelphia: Lippincott; 1994. p. 55-62.

16. Melo RP, Moreira RP, Fontenele FC, Aguiar ASC, Joventino ES, Carvalho EC. Criteria for selection of experts for validation studies of nursing phenomena. Rev Rene[Internet]. 2011[cited 2018 Feb 18];12(2):424-31. Available from: http://periodicos.ufc.br/rene/ article/view/4255

17. Alexandre NMC, Coluci MZO. [Content validity in the development and adaptation processes of measurement]. Ciênc Saúde Colet[Internet]. 2011[cited 2017 Apr 9];16(7):3061-8. Available from: http://www.scielo.br/pdf/csc/v16n7/06.pdf Portuguese.

18. Pires MPO, Pedreira MLG, Peterlini MAS. Safe pediatric surgery: development and validation of preoperative interventions checklist. Rev Latino-Am Enfermagem[Internet]. 2013[cited 2017 Feb 10];21(5):1080-7. Available from: http://www.scielo.br/pdf/ rlae/v21n5/0104-1169-rlae-21-05-1080.pdf

19. Winters BD, Gurses AP, Lehmann H, Sexton JB, Rampersad CJ, Pronovost PJ. Clinical review: Checklists - translating evidence 
into practice. Crit Care[Internet]. 2009[cited 2017 Feb 10];13. Available from: https://www.ncbi.nlm.nih.gov/pubmed/20064195

20. Lima NDC, Silva VM, Beltrão BA. [Construction and validation of data collection instrument content in a neonatal intensive care unit]. Rev Rene[Internet]. 2009[cited 2017 Feb 10];10(3):97-106. Availabe from: http://periodicos.ufc.br/rene/article/view/4823/3561 Portuguese.

21. Félix RS, Zamberlan C, Backes DS, Filippin NT. [Using wristbands to create a standard operating procedure to identify neonates]. Discip Sci[Internet]. 2016[cited 2017 Feb 10];17(1):145-52. Available from: https://www.periodicos.unifra.br/index.php/disciplinarumS/ article/view/1915 Portuguese.

22. Brasil. Conselho Federal de Medicina. Recomendação CFM n 1, de 21 de janeiro de 2016. Diário Oficial da União[Internet]. 2016[cited 2016 May 20]. Available from: https://portal.cfm.org.br/images/Recomendacoes/1_2016.pdf

23. Brasil. Ministério da Saúde. Portaria n 158, de 4 de fevereiro de 2016. Diário Oficial da União[Internet]. $2016[$ cited 2016 May 20]. Available from: http://portalarquivos2.saude.gov.br/images/pdf/2016/abril/12/PORTARIA-GM-MS-N158-2016.pdf

24. Yeh SP, Chang CW, Chen JC, Yeh WC, Chen PC, Chuang SJ, et al. A well-designed online transfusion reaction reporting system improves the estimation of transfusion reaction incidence and quality of care in transfusion practice. Am J Clin Pathol[Internet]. 2011[cited 2017 Feb 10];136(6):842-7. Available from: https://www.ncbi.nlm.nih.gov/pubmed/22095368

25. Vasiliki K. Enhancing transfusion safety: nurse's role. Int J Car Sci[Internet]. 2011[cited 2017 Feb 10];4(3):114-9. Available from: http://www.internationaljournalofcaringsciences.org/docs/Vol4_Issue3_03_Kyriazi.pdf

26. Royal College of Nursing. Right blood, right patient, right time. RCN guidance for improving transfusion practice. London: Royal College of Nursing; 2005.

27. Bain A, Blackburn S. Issues in transfusing preterm infants in the NICU. J Perinat Neonat Nurs[Internet]. 2004[cited 2017 Feb 15];18(2):170-82. Available from: https://www.ncbi.nlm.nih.gov/pubmed/15214254

28. Brasil. Agência Nacional de Vigilância Sanitária. Marco conceitual e operacional da hemovigilância: guia para a hemovigilância no Brasil[Internet]. 2015[cited 2017 Apr 15]. Available from: http://portal.anvisa.gov.br/documents/33868/404938/Marco+ Conceitual + e + Operacional + de + Hemovigil\%C3\%A2ncia +- + Guia + para + a + Hemovigil\%C3\%A2ncia + no + Brasil/495 fd617-5156-447d-ad22-7211cdbab8a7 